$\sqrt{3}$

J. Bio-Sci. 29(1): 111-122, 2021 (June)

ISSN 1023-8654

http://www.banglajol.info/index.php/JBS/index

DOI: https://doi.org/10.3329/jbs.v29i0.54827

\title{
TEMPORAL VARIATIONS OF CONDITION FACTOR AND RELATIVE WEIGHT FOR MYSTUS GULIO (HAMILTON, 1822) FROM THE COASTAL WATER IN BANGLADESH
}

\author{
O Rahman ${ }^{1}$, MY Hossain ${ }^{1 *}$, M Ashekur Rahman', MA Islam¹, M Ataur Rahman'1, MF Parvin ${ }^{1}$, MS \\ Sarmin ${ }^{1}$, BK Sarker ${ }^{1}$, W Sabbir ${ }^{2}$ and KA Habib ${ }^{3}$
}

${ }^{1}$ Department of Fisheries, University of Rajshahi, Rajshahi-6205, Bangladesh

${ }^{2}$ Fisheries and Marine Resource Technology Discipline, Khulna University, Khulna-9208, Bangladesh

${ }^{3}$ Department of Fisheries Biology and Genetics, Faculty of Fisheries, Aquaculture and Marine Science, Shere-Bangla Agricultural University, Dhaka-1207, Bangladesh

\begin{abstract}
The long whiskers catfish, Mystus gulio (Hamilton, 1822), is a valuable, delicious food fish in coastal areas of Bangladesh. It is found in fresh and brackish water of South Asian region. The present study illustrates the temporal variation of condition factor $\left(K_{F}\right)$ and prey-predator through relative weight $\left(W_{R}\right)$ along with length-weight relation (LWR) of $M$. gulio in the Maloncho River at southern Bangladesh. There were a total of 1200 individuals collected between January-December 2017 and October 2019 to June 2020. Different traditional gears (such as cast net, seine net, square lift net) were used for collecting the fish samples. There were $35 \%$ males and $65 \%$ females. The total length of fish ranged 7.8-18.3 cm for males and 9.3-22.1 cm for females. The body weight ranged $8.80-72.34 \mathrm{~g}$ for males and 8.09-128.82 $\mathrm{g}$ for females. LWR was significant with $r^{2}$ value $>0.950$. The calculated co-efficient $(b)$ were negative allometric growth in male and female $(b<3.0, p<0.001)$. The $K_{F}$ indicated the best condition of this species. $W_{R}$ revealed no significant difference from 100 for both sex $(p=0.441)$ and females $(p=$ 0.221 ), indicating a suitable habitat for growth. From conservation point of view, the findings of this present study on M. gulio will be helpful in Bangladesh (Maloncho River) and neighboring countries.
\end{abstract}

Key words: Coastal waters, Condition factor, Maloncho River, Mystus gulio, Relative weight

\section{Introduction}

The long whisker catfish M. gulio found in fresh and brackishwater, and is a demersal anadromous species (Riede 2004). It is generally recognized as the 'river catfish'. It is known as Nona tengra in Bangladesh, Ngazin in Mayanmar and long whisker catfish in India and Sri Lanka. There are other names of M. gulio in India such as Kala tenguah, shingati, kontia and katta-keluthi (Froese and Pauly 2018). The species is generally

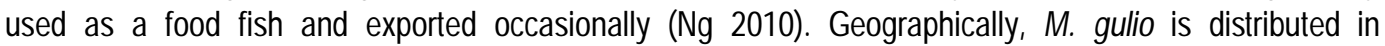
Bangladesh, India, Indonesia, Pakistan, Nepal, Myanmar and Viet Nam (Talwar and Jhingran 1991, Menon 1999, Riede 2004).

Both in local and commercial perspective, the species are valuable for coastal fisheries in Bangladesh. Though, the fish harvested naturally, it is gradually decreasing as a result of destructive fishing, overexploitation, ecological modifications and loss of habitat (Alam et al. 2006). The condition factor is an important biological parameter in the assessment of stock health of fish population (Bagenal and Tesch 1978). Essentially, conditions of aquatic animal reveal environmental (abiotic and biotic) status, fluctuation of

*Author for correspondence: hossainyeamin@gmail.com, yeamin.fish@ru.ac.bd 
feeding condition in which they interact, physiological factors and infections of parasites (Le Cren 1951). The relative weight $\left(W_{R}\right)$ makes it possible to recognize environmental changes as well as physiological components of the life history of fish (lipid storage and growth) and to evaluate the overall health and ecosystem disturbance (Rypel and Richter 2008).

There is no available literature on the condition factor of $M$. gulio. Previous studies on $M$. gulio included age and growth (Pantulu 1961), growth and survival (Islam et al. 2007), biometry and length-weight relationship (Dasgupta 1997), morphology and growth pattern (Gupta 2014), length-weight and length-length relationships (Hossain et al. 2016a). Details statistics on life-history traits of $M$. gulio is necessary for its management and to instigate protection strategies in the Maloncho River, southern Bangladesh and neighboring countries. This study deals with the temporal variation of condition factor, relative weight, preypredator status of M. gulio in the Maloncho River. The purposes of this study are to realize fisheries data for formulating management policies for M. gulio.

\section{Materials and Methods}

\section{Study site and sampling}

In the Maloncho River, samples were collected from Satkhira (Latitude $21^{\circ} 40^{\prime} \mathrm{N}$; Longitude $89^{\circ} 35^{\prime} \mathrm{E}$ ) from January-December 2017 and October 2019 to June 2020. A total of 1200 specimens (male $=420$, female $=$ 780) of $M$. gulio were collected from commercial fishermen, who caught $M$. gulio using gill net, cast net and seine net (mesh size 1.5 - 2.5, $1.0-2.0$ and $\sim 1.0 \mathrm{~cm}$ ). The samples were immediately preserved on the spot with ice and then fixed on arrival at the workplace with a $10 \%$ formalin solution.

\section{Fish measurement}

Microscopic observation of gonads, and morphometric and meristic characters, and identification of sex were carried out. The total length (TL), standard length (SL) and fork length $(\mathrm{FL})$ and body weight (BW) were measured via digital balance and with digital slide calipers.

\section{Length-weight relationship (LWR)}

The relation between length and weight (LWR) was measured using $W=a^{*} L^{b}$, where $W$ is the total body weight (BW, $g$ ), $L$ is the total length $(T L, C m), a \& b$ are regression parameters. LWR parameters $a$ and $b$ were determined by $\ln (W)=\ln (a)+b \ln \ln (L)$. T-test was used for substantial deviation from the isometric value of $b=3$ to validate the growth trend, either isometric or ( $+/-$ ) allometric (Sokal and Rohlf 1987).

\section{Condition factor}

Monthly condition factor for $M$. gulio was calculated using samples with small to bigger body sizes. Fulton's condition factor (Fulton 1904) was obtained by $K_{F}=100 \times\left(W / L^{3}\right)$, where 100 for scaling factor, the total body weight (BW, $g$ ) is $W$ and the total length $L$ is $(T L, c m)$.

\section{Relative weight $\left(W_{R}\right)$}

The relative weight was measured by $W_{R}=\left(W / W_{S}\right) \times 100$ (Froese 2006), where $W_{s}=a L^{b}, W_{s}$ is the estimated standard weight for the particular individual (where $a$ and $b$ values were deliberated from TL and BW relationships). 


\section{Statistical analyses}

GraphPad Prism 6.5 software was used for statistical analysis. Homogeneity and data normality were tested. To check the difference of growth type between the sexes, ANCOVA was used. Wilcoxon sign ranked test was performed to know prey-predator status. Statistical significance was tested at $5 \%$ level $(p<0.05)$.

\section{Results}

During the study, a total of 1200 (males $=420$ and females $=780$ ) individuals of $M$. gulio were collected from the Maloncho River, comprising 35\% males and 65\% females. Table 1 shows the specimen size $(7.80-18.3$ $\mathrm{cm}$ TL for male; 9.30-22.1 cm TL for females) and body weight (8.80-72.3 $4 \mathrm{~g}$ for males; 8.09-128.82 $\mathrm{g}$ for females).

Table 1. Descriptive statistics for the length $(\mathrm{cm})$ and weight $(\mathrm{g})$ of Mystus gulio (Hamilton, 1822) in the Maloncho River, southern Bangladesh

\begin{tabular}{ccccccc}
\hline Parameter & Sex & $n$ & Min. & Max. & Mean \pm SD & $95 \% \mathrm{CL}$ \\
\hline TL & & & 7.80 & 18.30 & $11.54 \pm 1.18$ & $11.36-11.71$ \\
FL & Male & & 7.20 & 15.80 & $10.14 \pm 1.97$ & $10.00-10.28$ \\
SL & & 420 & 6.70 & 15.00 & $9.54 \pm 1.41$ & $9.410-9.610$ \\
BW & & 8.80 & 72.34 & $24.73 \pm 10.53$ & $23.72-25.74$ \\
\hline TL & & 9.30 & 22.10 & $13.29 \pm 2.61$ & $13.11-13.48$ \\
FL & \multirow{2}{*}{ Female } & 780 & 7.20 & 18.70 & $11.58 \pm 2.09$ & $11.43-11.73$ \\
SL & & & 6.80 & 17.50 & $10.95 \pm 1.99$ & $10.81-11.09$ \\
BW & & 8.09 & 128.8 & $36.59 \pm 19.03$ & $35.26-37.93$ \\
\hline
\end{tabular}

$\mathrm{TL}=$ total length, $\mathrm{FL}=$ fork length, $\mathrm{SL}=$ standard length, $\mathrm{BW}=$ body weight, $n=$ sample size, Min. $=$ minimum, Max. = maximum, $\mathrm{SD}=$ standard deviation, $\mathrm{CL}=$ confidence limit for mean values.

\section{Length-weight relationship}

Sample sizes $(n)$, regression parameters and confidence intervals of $95 \%$ for $a$ and $b$ of $L W R s$, determination coefficient $\left(r^{2}\right)$ and growth of $M$. gulio are shown in Table 2 and Figs. 1, 2, respectively. The $b$ values for TLBW relationships showed negative allometric growth in males mostly for the 12 months. LWR was highly significant with all $r^{2}$ values $\geq 0.951$. ANCOVA revealed that there was no significant difference between males and females for the intercepts ( $\ln a),(F=0.613, d f=1196, p<0.4337)$ and also for slopes $(b),(F=$ $2.924, d f=1197, p=0.0874)$. 
Table 2. Descriptive statistics and estimated parameters of the length-weight relationship $\left(B W=a \times T L^{b}\right)$ of Mystus gulio (Hamilton, 1822) in the Maloncho River, southern Bangladesh

\begin{tabular}{|c|c|c|c|c|c|c|c|c|}
\hline Month & Sex & $n$ & a & $b$ & $95 \% \mathrm{CL}$ of $a$ & $95 \% \mathrm{CL}$ of $b$ & $r^{2}$ & GT \\
\hline & M & 34 & 0.0474 & 2.61 & $0.0337-0.0668$ & $2.47-2.76$ & 0.978 & $-A$ \\
\hline \multirow[t]{2}{*}{ January } & $\mathrm{F}$ & 66 & 0.0511 & 2.53 & $0.0430-0.0608$ & $2.46-2.60$ & 0.988 & $-A$ \\
\hline & M & 34 & 0.0467 & 2.52 & $0.0318-0.0686$ & $2.36-2.67$ & 0.972 & $-A$ \\
\hline \multirow[t]{2}{*}{ February } & $F$ & 66 & 0.0441 & 2.54 & $0.0318-0.0611$ & $2.41-2.66$ & 0.962 & $-A$ \\
\hline & M & 29 & 0.0524 & 2.52 & $0.0392-0.0700$ & $2.40-2.64$ & 0.986 & $-A$ \\
\hline \multirow[t]{2}{*}{ March } & $\mathrm{F}$ & 71 & 0.0513 & 2.51 & $0.0430-0.0611$ & $2.44-2.57$ & 0.988 & $-A$ \\
\hline & M & 30 & 0.0445 & 2.54 & $0.0295-0.0670$ & $2.38-2.70$ & 0.974 & $-A$ \\
\hline \multirow[t]{2}{*}{ April } & $F$ & 70 & 0.0457 & 2.53 & $0.0365-0.0572$ & $2.45-2.61$ & 0.982 & $-A$ \\
\hline & M & 44 & 0.0168 & 2.84 & $0.0114-0.0247$ & $2.69-2.99$ & 0.972 & $-A$ \\
\hline \multirow[t]{2}{*}{ May } & $\mathrm{F}$ & 56 & 0.0195 & 2.85 & $0.0126-0.0301$ & $2.69-3.01$ & 0.960 & $-A$ \\
\hline & M & 37 & 0.0446 & 2.58 & $0.0272-0.0729$ & $2.37-2.78$ & 0.951 & $-A$ \\
\hline \multirow[t]{2}{*}{ June } & $\mathrm{F}$ & 63 & 0.0511 & 2.50 & $0.0387-0.0674$ & $2.40-2.60$ & 0.975 & $-A$ \\
\hline & M & 27 & 0.0540 & 2.50 & $0.0336-0.0867$ & $2.30-2.71$ & 0.964 & $-A$ \\
\hline \multirow[t]{2}{*}{ July } & $\mathrm{F}$ & 73 & 0.0401 & 2.58 & $0.0309-0.0522$ & $2.47-2.68$ & 0.970 & $-A$ \\
\hline & M & 38 & 0.0520 & 2.53 & $0.0377-0.0718$ & $2.40-2.67$ & 0.977 & $-A$ \\
\hline \multirow[t]{2}{*}{ August } & $\mathrm{F}$ & 62 & 0.0583 & 2.50 & $0.0448-0.0758$ & $2.40-2.60$ & 0.976 & $-A$ \\
\hline & M & 32 & 0.0207 & 2.92 & $0.0114-0.0373$ & $2.67-3.17$ & 0.957 & $-A$ \\
\hline \multirow[t]{2}{*}{ September } & $\mathrm{F}$ & 68 & 0.0233 & 2.89 & $0.0159-0.0340$ & $2.74-3.05$ & 0.956 & $-A$ \\
\hline & M & 43 & 0.0454 & 2.52 & $0.0329-0.0627$ & $2.39-2.66$ & 0.973 & $-A$ \\
\hline \multirow[t]{2}{*}{ October } & $\mathrm{F}$ & 57 & 0.0506 & 2.52 & $0.0359-0.0714$ & $2.39-2.65$ & 0.963 & $-A$ \\
\hline & M & 35 & 0.0299 & 2.77 & $0.0193-0.0465$ & $2.58-2.96$ & 0.965 & $-A$ \\
\hline \multirow[t]{2}{*}{ November } & $F$ & 65 & 0.0488 & 2.52 & $0.0356-0.0670$ & $2.40-2.65$ & 0.964 & $-A$ \\
\hline & M & 36 & 0.0421 & 2.63 & $0.0293-0.0604$ & $2.48-2.78$ & 0.974 & $-A$ \\
\hline December & $\mathrm{F}$ & 64 & 0.0490 & 2.54 & $0.0387-0.0621$ & $2.44-2.63$ & 0.977 & $-A$ \\
\hline
\end{tabular}

$n=$ sample size, $a=$ intercept, $b=$ slope,$C L=$ confidence limit for mean values, $r^{2}=$ co-efficient of determination, $\mathrm{GT}=$ growth type, $\mathrm{M}=$ male, $\mathrm{F}=$ female, $\mathrm{A}=$ negative allometric . 


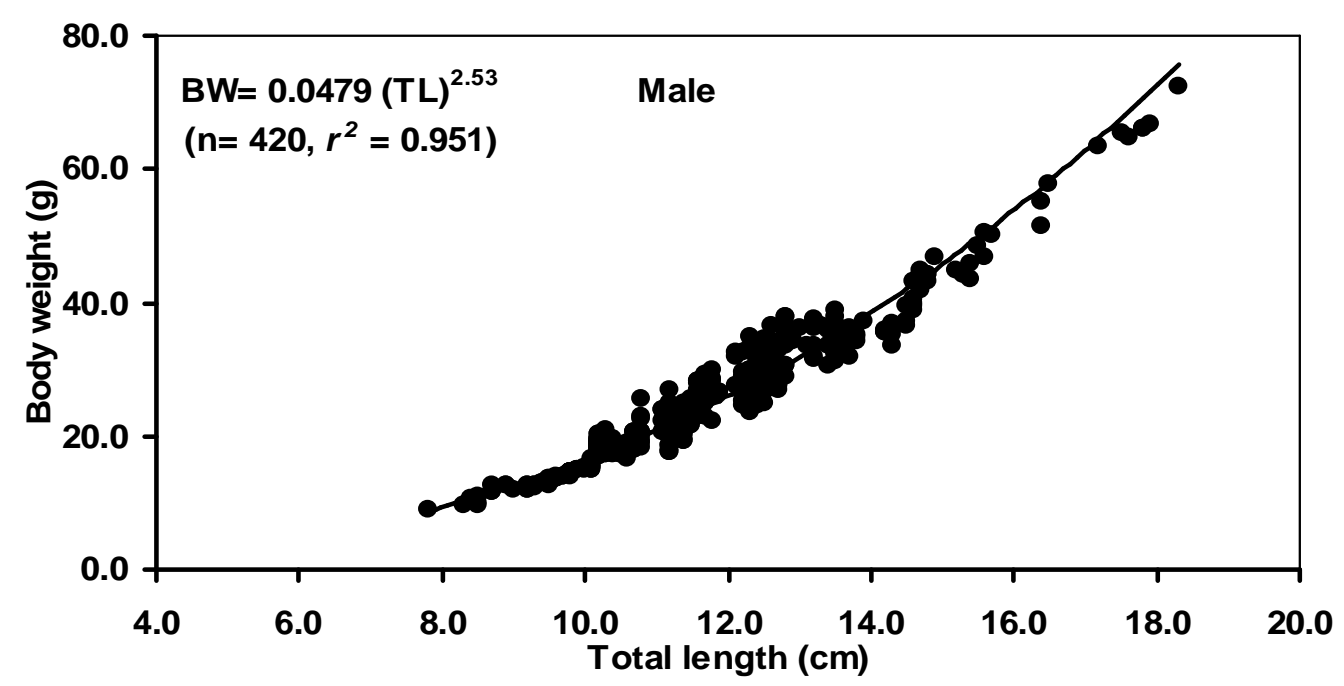

Fig. 1: Length-weight relationship of male Mystus gulio in the Maloncho River, southern Bangladesh.

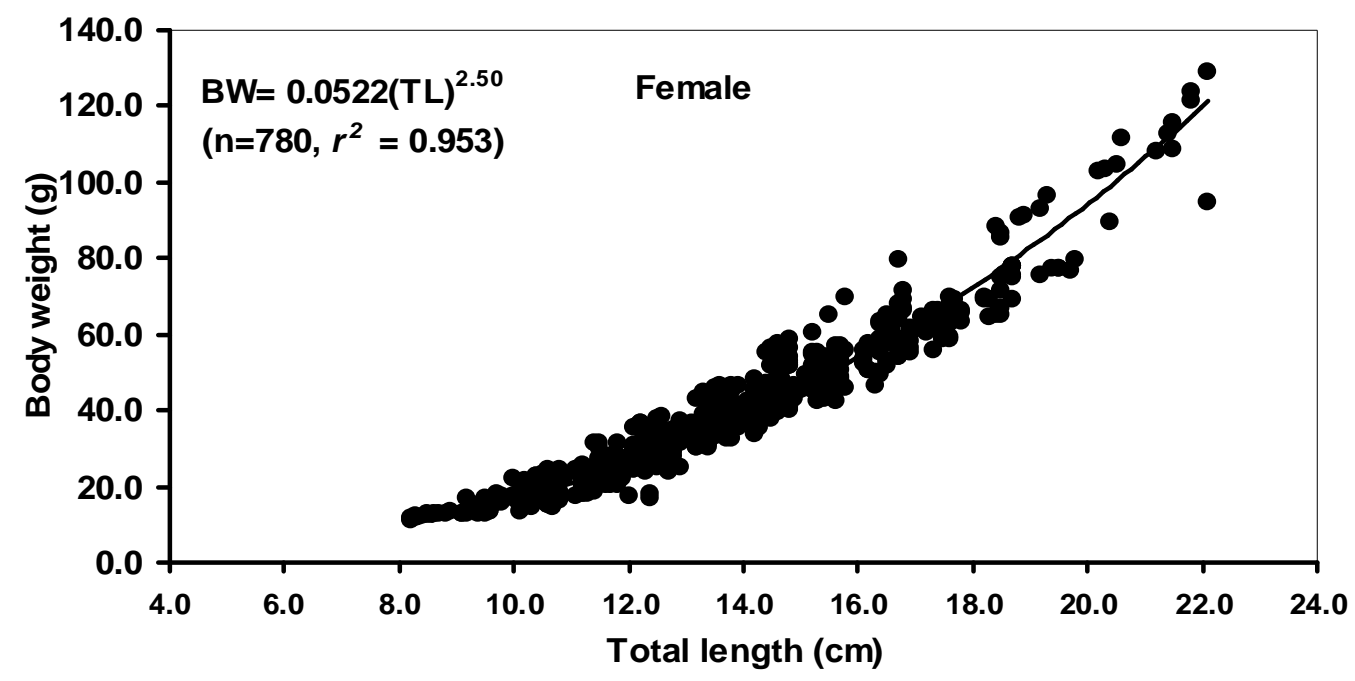

Fig. 2: Length-weight relationship of female Mystus gulio in the Maloncho River, southern Bangladesh.

\section{Condition factor}

Fulton's condition factor $\left(K_{F}\right)$

$K_{F}$ ranged 0.890-2.217 $(\mathrm{Mean} \pm \mathrm{SD}=1.549 \pm 0.169,95 \% \mathrm{CL}=1.533-1.566)$ for males and $0.995-2.187$ (Mean $\pm S D=1.473 \pm 0.211,95 \% \mathrm{CL}=1.458-1.488$ ) for females (Table 3, Figs. 3, 4). There was important 
relationship between BW vs. $\mathrm{K}_{\mathrm{F}}$ according to the spearmen rank correlation test $\left(r_{s}=-0.4801, \mathrm{p}<0.0001\right)$ and TL vs. $K_{F}\left(r_{s}=-0.6423, p<0.0001\right)$ for both sexes.

Table 3. Fulton's condition factor $\left(K_{F}\right)$ of Mystus gulio (Hamilton, 1822) in the Maloncho River, southern Bangladesh

\begin{tabular}{|c|c|c|c|c|c|c|}
\hline \multirow[t]{2}{*}{ Month } & \multirow[t]{2}{*}{ Sex } & \multirow[t]{2}{*}{$n$} & \multicolumn{4}{|c|}{ Fulton's condition factor $\left(K_{F}\right)$} \\
\hline & & & Min. & Max. & Mean \pm SD & $95 \% \mathrm{CL}$ \\
\hline & M & 34 & 1.651 & 2.096 & $1.882 \pm 0.113$ & $1.843-1.922$ \\
\hline \multirow[t]{2}{*}{ January } & $\mathrm{F}$ & 66 & 1.370 & 1.844 & $1.599 \pm 0.148$ & $1.562-1.635$ \\
\hline & M & 34 & 1.204 & 1.619 & $1.412 \pm 0.131$ & $1.366-1.458$ \\
\hline \multirow[t]{2}{*}{ February } & $\mathrm{F}$ & 66 & 1.032 & 1.579 & $1.328 \pm 0.147$ & $1.292-1.364$ \\
\hline & $M$ & 29 & 1.412 & 1.840 & $1.648 \pm 0.113$ & $1.605-1.691$ \\
\hline \multirow[t]{2}{*}{ March } & $\mathrm{F}$ & 71 & 1.188 & 1.828 & $1.435 \pm 0.140$ & $1.402-1.468$ \\
\hline & M & 30 & 1.148 & 1.668 & $1.398 \pm 0.141$ & $1.346-1.452$ \\
\hline \multirow[t]{2}{*}{ April } & $\mathrm{F}$ & 70 & 0.995 & 1.553 & $1.292 \pm 0.162$ & $1.254-1.331$ \\
\hline & M & 44 & 0.890 & 1.504 & $1.130 \pm 0.122$ & $1.068-1.142$ \\
\hline \multirow[t]{2}{*}{ May } & $\mathrm{F}$ & 56 & 0.898 & 1.819 & $1.303 \pm 0.181$ & $1.254-1.351$ \\
\hline & M & 37 & 1.348 & 1.859 & $1.581 \pm 0.142$ & $1.534-1.629$ \\
\hline \multirow[t]{2}{*}{ June } & $\mathrm{F}$ & 63 & 1.124 & 1.521 & $1.342 \pm 0.123$ & $1.311-1.375$ \\
\hline & M & 27 & 1.479 & 1.942 & $1.675 \pm 0.111$ & $1.631-1.719$ \\
\hline \multirow[t]{2}{*}{ July } & $\mathrm{F}$ & 73 & 1.210 & 1.730 & $1.470 \pm 0.116$ & $1.390-1.445$ \\
\hline & M & 38 & 1.436 & 2.217 & $1.694 \pm 0.189$ & $1.632-1.757$ \\
\hline \multirow[t]{2}{*}{ August } & $\mathrm{F}$ & 62 & 1.258 & 2.155 & $1.625 \pm 0.173$ & $1.581-1.669$ \\
\hline & M & 32 & 1.543 & 1.897 & $1.705 \pm 0.105$ & $1.667-1.743$ \\
\hline \multirow[t]{2}{*}{ September } & $\mathrm{F}$ & 68 & 1.461 & 2.187 & $1.798 \pm 0.159$ & $1.759-1.836$ \\
\hline & M & 43 & 1.265 & 1.742 & $1.430 \pm 0.110$ & $1.396-1.464$ \\
\hline \multirow[t]{2}{*}{ October } & $\mathrm{F}$ & 57 & 1.272 & 1.748 & $1.483 \pm 0.132$ & $1.448-1.518$ \\
\hline & $M$ & 35 & 1.597 & 1.867 & $1.750 \pm 0.072$ & $1.725-1.774$ \\
\hline \multirow[t]{2}{*}{ November } & $\mathrm{F}$ & 65 & 1.187 & 1.811 & $1.434 \pm 0.148$ & $1.397-1.470$ \\
\hline & $M$ & 36 & 1.493 & 2.097 & $1.736 \pm 0.150$ & $1.685-1.787$ \\
\hline December & $\mathrm{F}$ & 64 & 1.357 & 2.158 & $1.611 \pm 0.177$ & $1.567-1.655$ \\
\hline
\end{tabular}

$n=$ sample size, Min. = minimum, Max. = maximum, $\mathrm{SD}=$ standard deviation, $\mathrm{CL}=$ confidence limit for mean values. 


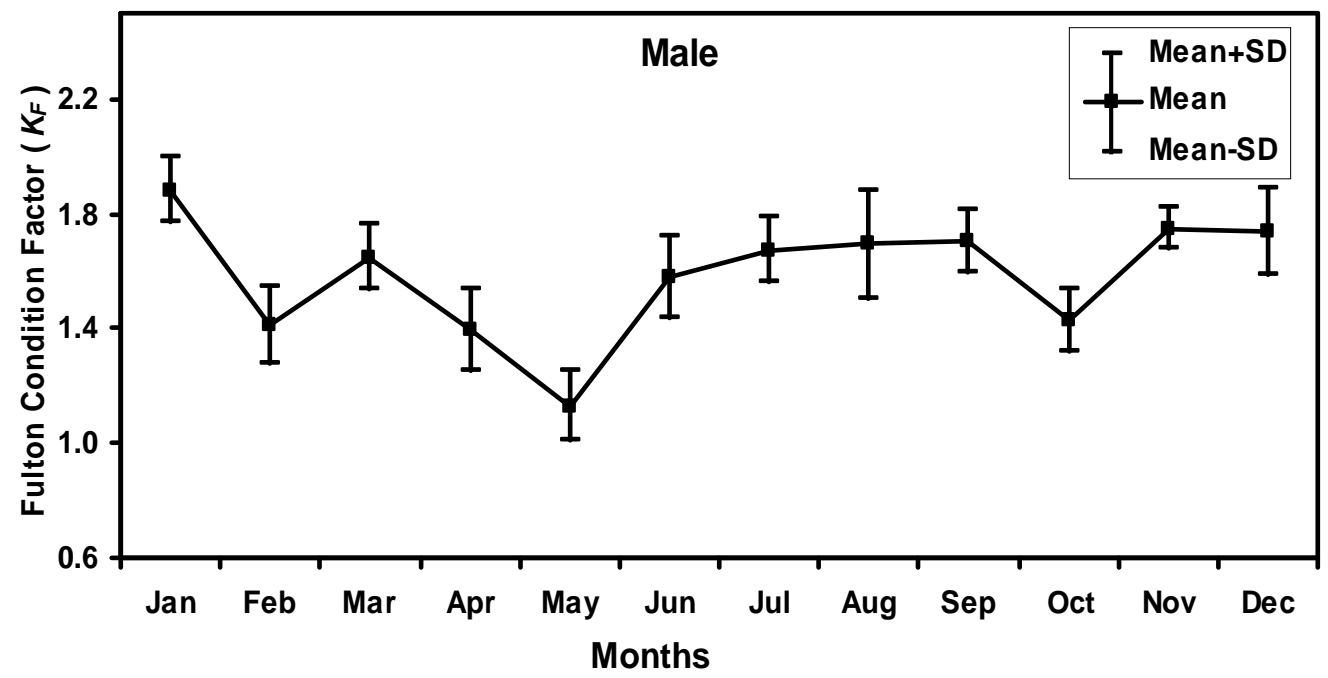

Fig. 3: Monthly variation of Fulton's condition factor $\left(K_{F}\right)$ for male Mystus gulio (Hamilton, 1822) in the Maloncho River, southern Bangladesh.

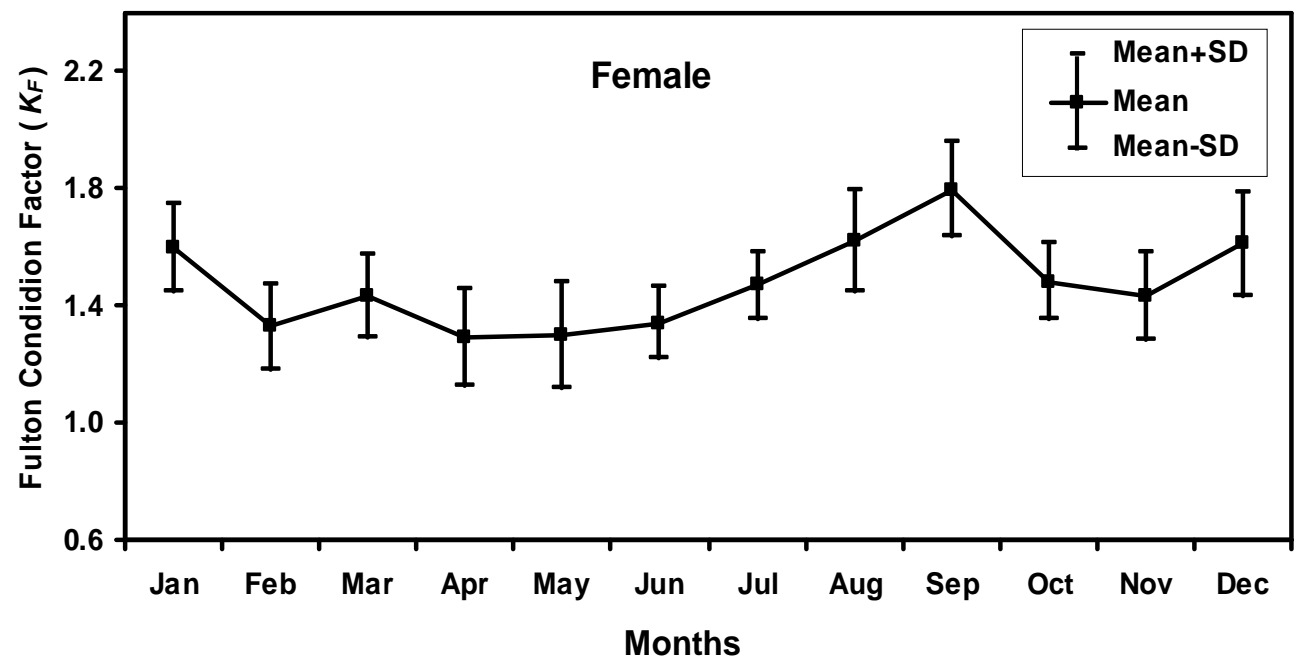

Fig. 4: Monthly variation of Fulton's condition factor $\left(K_{F}\right)$ for female Mystus gulio (Hamilton, 1822) in the Maloncho River, southern Bangladesh.

\section{Relative weight $\left(W_{R}\right)$}

The calculated $W_{R}$ for the males were 77.034-129.490 (Mean $\pm S D=100.414 \pm 8.851,95 \% \mathrm{CL}=99.570$ 101.260) and for females were 68.944-137.574 (Mean $\pm S D=100.654 \pm 10.828,95 \% \mathrm{CL}=99.890-101.420)$ 
(Table 4, Figs. 5, 6). According to spearmen rank correlation test, there was significant relationship between BW vs. $W_{R}\left(r_{s}=0.2080 p<0.001\right)$, but not TL vs. $W_{R}\left(r_{s}=0222 p<0.4415\right)$ for both. According to ShapiroWilk normality test, $W_{R}$ between sexes did not show normality $(p<0.0001)$ and for both males and females, the graded Wilkoxon sign test showed no major differences from 100.

Table 4. Relative weight $\left(W_{R}\right)$ of Mystus gulio (Hamilton, 1822) in the Maloncho River, southern Bangladesh

\begin{tabular}{|c|c|c|c|c|c|c|}
\hline \multirow[t]{2}{*}{ Month } & \multirow[t]{2}{*}{ Sex } & \multirow[t]{2}{*}{$n$} & \multicolumn{4}{|c|}{ Relative weight $\left(W_{R}\right)$} \\
\hline & & & Min. & Max. & Mean \pm SD & $95 \% \mathrm{CL}$ \\
\hline & M & 34 & 94.024 & 112.410 & $102.039 \pm 4.445$ & $100.489-103.590$ \\
\hline \multirow[t]{2}{*}{ January } & $\mathrm{F}$ & 66 & 91.706 & 114.002 & $101.093 \pm 4.851$ & $99.900-102.285$ \\
\hline & $M$ & 34 & 88.722 & 112.116 & $98.499 \pm 6.112$ & $96.366-100.632$ \\
\hline \multirow[t]{2}{*}{ February } & $\mathrm{F}$ & 66 & 84.064 & 114.241 & $99.647 \pm 8.324$ & $97.601-101.693$ \\
\hline & M & 29 & 93.767 & 107.736 & $100.487 \pm 3.749$ & $99.061-101.914$ \\
\hline \multirow[t]{2}{*}{ March } & $\mathrm{F}$ & 71 & 83.889 & 110.566 & $99.447 \pm 4.671$ & $98.341-100.553$ \\
\hline & M & 30 & 83.330 & 110.285 & $98.881 \pm 6.595$ & $96.418-101.344$ \\
\hline \multirow[t]{2}{*}{ April } & $\mathrm{F}$ & 70 & 84.152 & 112.196 & $98.927 \pm 7.346$ & $97.176-100.679$ \\
\hline & M & 44 & 77.034 & 129.490 & $100.07 \pm 10.069$ & $97.170-103.293$ \\
\hline \multirow[t]{2}{*}{ May } & $\mathrm{F}$ & 56 & 68.944 & 137.574 & $103.322 \pm 13.548$ & $99.694-106.950$ \\
\hline & M & 37 & 87.163 & 111.139 & $98.114 \pm 7.160$ & $95.726-100.501$ \\
\hline \multirow[t]{2}{*}{ June } & $\mathrm{F}$ & 63 & 90.307 & 114.337 & $100.282 \pm 6.039$ & $98.761-101.803$ \\
\hline & M & 27 & 89.145 & 109.727 & $100.038 \pm 4.597$ & $98.220-101.857$ \\
\hline \multirow[t]{2}{*}{ July } & $\mathrm{F}$ & 73 & 88.376 & 113.602 & $100.611 \pm 5.919$ & $99.230-101.992$ \\
\hline & M & 38 & 82.921 & 113.210 & $100.282 \pm 6.718$ & $98.073-102.489$ \\
\hline \multirow[t]{2}{*}{ August } & $\mathrm{F}$ & 62 & 87.109 & 114.074 & $100.185 \pm 6.710$ & $98.481-101.889$ \\
\hline & M & 32 & 90.705 & 110.843 & $99.996 \pm 6.103$ & $97.797-102.197$ \\
\hline \multirow[t]{2}{*}{ September } & $\mathrm{F}$ & 68 & 80.128 & 119.727 & $100.281 \pm 8.681$ & $98.180-102.381$ \\
\hline & M & 43 & 89.554 & 109.902 & $100.118 \pm 4.958$ & $98.592-101.644$ \\
\hline \multirow[t]{2}{*}{ October } & $\mathrm{F}$ & 57 & 84.670 & 111.533 & $100.216 \pm 6.246$ & $98.558-101.873$ \\
\hline & M & 35 & 94.858 & 106.895 & $100.145 \pm 3.799$ & $98.840-101.450$ \\
\hline \multirow[t]{2}{*}{ November } & $\mathrm{F}$ & 65 & 86.258 & 118.117 & $100.274 \pm 7.411$ & $98.437-102.110$ \\
\hline & M & 36 & 85.906 & 110.073 & $100.107 \pm 6.339$ & $97.962-102.251$ \\
\hline December & $\mathrm{F}$ & 64 & 86.183 & 112.173 & $98.007 \pm 6.328$ & $96.427-99.588$ \\
\hline
\end{tabular}

$n=$ sample size, Min. $=$ minimum, Max. $=$ maximum,$S D=$ standard deviation, $C L=$ confidence limit for mean values, $\mathrm{M}=$ male, $\mathrm{F}=$ female. 


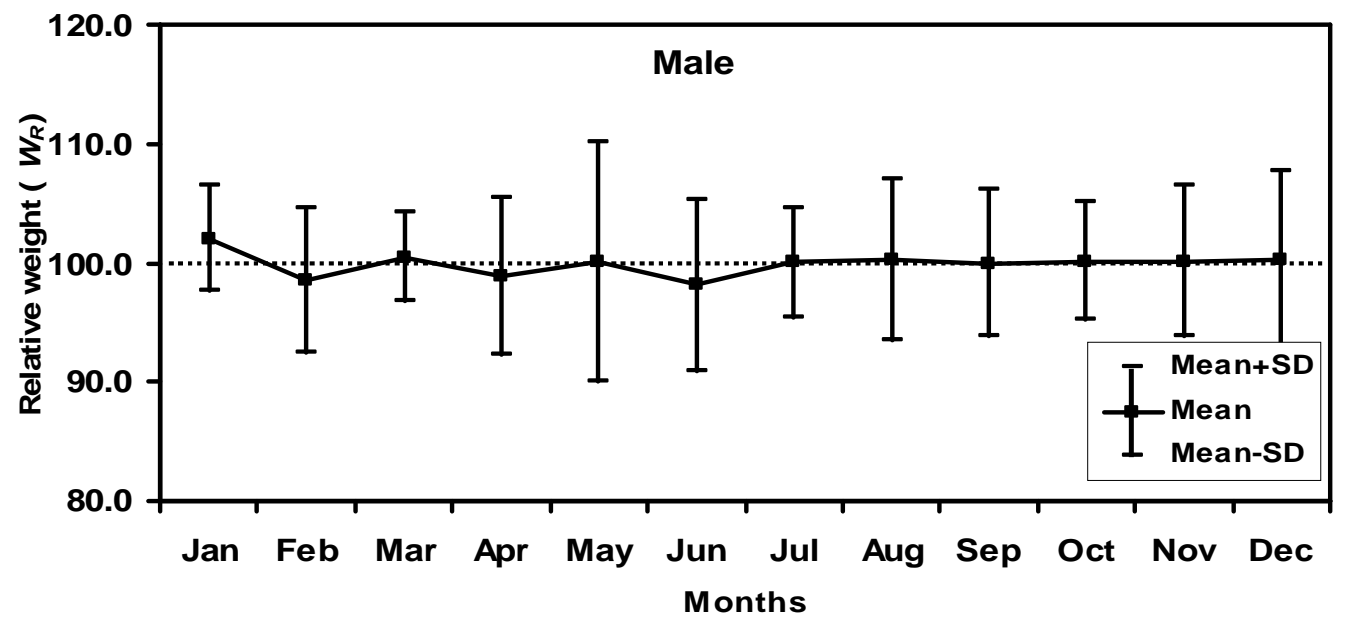

Fig. 5: Monthly changes of relative weight $\left(W_{R}\right)$ for male Mystus gulio in the Maloncho River, southern Bangladesh.

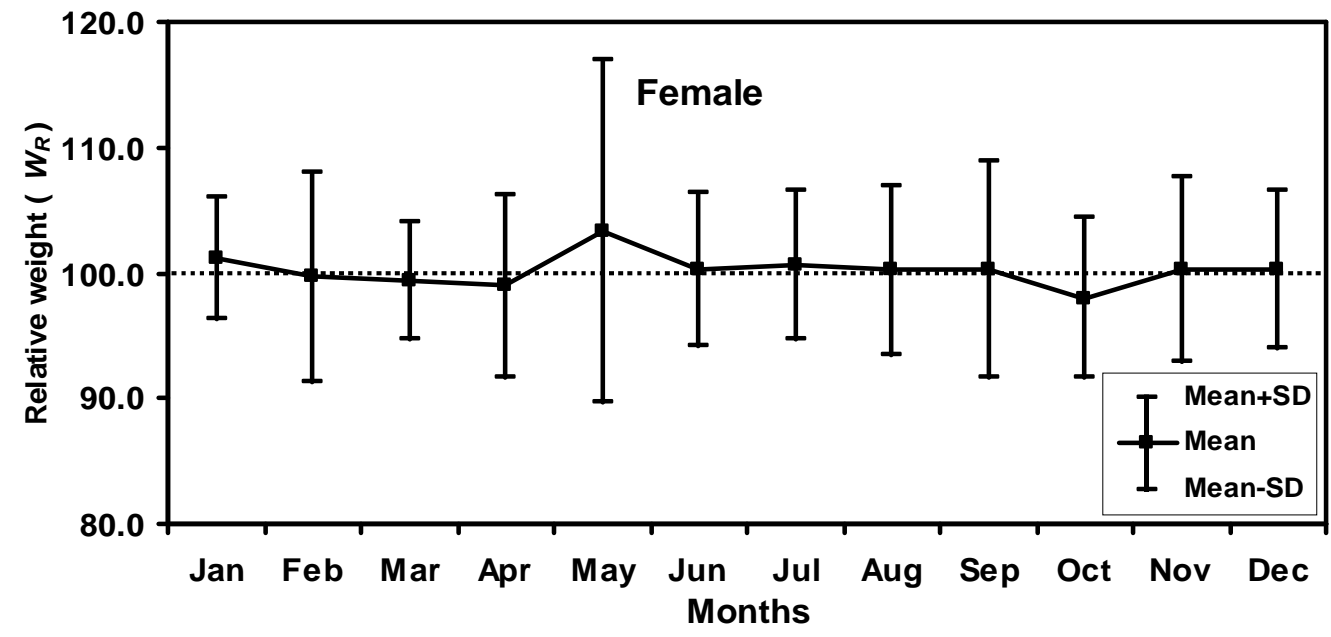

Fig. 6: Monthly changes of relative weight $\left(W_{R}\right)$ for female Mystus gulio in the Maloncho River, southern Bangladesh.

\section{Discussion}

Information on temporal variation of $M$. gulio is scare in the literature. As it is a commercial food fish in the Asian countries and the practice of aquaculture is yet to realize, consequently, the demand of this fish is high in the domestic market. Therefore, effective assessment of wild stocks of $M$. gulio is essential. The present study determines the temporal variation of condition factor and prey-predator status of $M$. gulio in the Maloncho River. 
During present study, a total of 1200 specimens with different body sizes were captured using traditional fishing gear from the Maloncho River. However, it was not possible to catch fishes $<7.8 \mathrm{~cm}$ TL and $>22.1 \mathrm{~cm}$ TL that may be attributed to the selectivity of fishing gear. The maximum length of $M$. gulio was $22.1 \mathrm{~cm}$ which is higher than those recorded from the Chilika lagoon, India ( $T L=21.5 \mathrm{~cm}$; Panda et al. 2016), and from the Rupsha River, Bangladesh ( $T L=17.2 \mathrm{~cm}$; Hossain et al. 2016a). Knowledge on maximum length of fish is useful for the calculation of asymptotic length and growth coefficient as well as for the planning and management of fishery resources (Hossain et al. 2012, 2016b). The values of parameter $b$ range from 2.5 to 3.5 (Froese 2006) and the value of $b$ in the analysis was within this limit. When $b$ is close to $3(b \approx 3.0)$, isometric growth is indicated, $b>3.0$ indicates positive allometric growth and $b<3$ indicates negative allometric growth (Tesch 1971). In most of the months, both sexes had negative allometric growth on the basis of bvalues. In the existent study, the regression parameter $b$ of LWR ranged 2.50-2.84 for males and 2.50-2.85 for females. The $b$ values for TL-BW relationships indicate negative allometric growth in males. The overall $b$ for the LWR suggested negative allometric growth $(<3.0)$ in both males and females in the existent analysis. In addition, for both sexes, the overall growth trend was negative allometric. However, positive allometric was reported from Rupsha River, Bangladesh $(b=3.11)$ by Hossain et al. (2016a), isometric growth pattern was reported from Chilika lagoon, India $(b=3.03)$ by Panda et al. (2016) and negative allometric was reported from Narreri Lagoon, Pakistan $(b=2.20)$ by Haroun et al. (2017). However, the growth pattern may vary due to habitat condition, seasonal impact, stomach fullness level, maturation of gonads, health, method of preservation and variations in the observation of sample collection length groups (Tesch 1971, Weatherley and Gill 1987), all of which were not considered in the study.

The condition factor is one of the traditional fisheries procedures used as a measure of the variability due to the growth coefficient. It expresses the state of a fish in numerical terms, such as the degree of well-being in its natural environment, relative strength or fatness. The condition factor of Fulton $\left(K_{\mathrm{F}}\right)$ is an index that represents interactions in the physiological condition of fishes between biotic and abiotic factors. When the value of this condition factor is greater, it indicates that the fish have reached a better condition. In this study, the $K_{F}$ ranged from $0.890-2.217$ for males and $0.995-2.187$ for females. According to the spearmen rank correlation test, both $\mathrm{BW}$ and $K_{F}$ were significantly linked $\left(r_{s}=-0.480, p<0.0001\right)$ and $\mathrm{TL}$ vs. $\mathrm{K}_{\mathrm{F}}\left(r_{s}=\right.$ $0.642, p<0.0001)$. In general, a relationship with gonadal production was indicated by the seasonal cycle in fish conditions (Hossain et al. 2006). Monthly $K_{F}$ values have increased and $b$ values have decreased between June to September, suggesting the spawning season. A number of factors, such as stress, sex, season, feed availability, and other parameters of water quality, may affect the $K_{F}$ of fish (Khallaf et al. 2003). Therefore, it can be assumed that, the Fulton's condition factor $\left(K_{F}\right)$ is the best for determining the well-being of $M$. gulio in the Maloncho River and adjacent ecosystem.

Relative weight is the most popular index to assess the status of fish in a habitat (Froese 2006). Relative weight can be used to estimate the condition of fish health (Rypel and Richter 2008). According to Porath and Peters (1997) $W_{R}$ influenced the prey availability in a population. There is a significant correlation between relative weight, prey and predator availability (Kohler and Kelly 1991). Prey-predator status of a water body affects the fisheries community and the recruitment pattern (Shulman and Ogden 1987). The values of $W_{R}$ falling below 100 for an individual or population recommend problems such as low prey accessibility or high predator density; whereas values above 100 indicates a prey surplus or low predator density (Rypel and Richter 2008). In our study the mean $W_{R}$ was not significantly different from 100 for both females and males populations of $M$. gulio indicating a balance habitat (Anderson and Neumann 1996) in the Maloncho River.

$W_{R}$ was higher in the month of January for male and May for female populations of M. gulio that represent in these months the predator was in lower amount and prey was in higher amount in the Maloncho River 
ecosystem. Also $W_{R}$ was very low in the month of June for male and October for female population of $M$. gulio that indicates in the June the predator was in higher amount for male and October for female, it may be due to the spatial distribution of fishes and climatic condition. $W_{R}$ of fishes may also be affected by physiological and behavioral aspects of fishes (Davis 2000).

\section{Acknowledgements}

Authors extend their sincere gratefulness to the Bangladesh Agricultural Research Council, Project Implementation Unit (PIU); National Agricultural Technology Program: Phase-II Project; Sub-Project ID: 156.

\section{Disclosure statement}

No possible conflict of interest identified by the authors was noted.

\section{References}

Alam MJ, Begum M, Islam MA and Pal HK (2006). Spawning behaviour and induced breeding of an estuarine catfish, Mystus gulio (Ham.). Bangladesh Journal of Fisheries Research, 10: 101-109.

Anderson RO and Neumann RM (1996). Length, weight and associated structural indices. In: Fisheries Techniques, edited by Murphy BR and Willis WD (2nd Ed.). American Fisheries Society Bethesda, Maryland, pp. 447-482.

Bagenal TB and Tesch FW (1978). Age and growth. In methods for assessment of fish production in fresh waters, $3^{\text {rd }}$ ed., edited by T Bagenal. IBP Handbook No.3, Blackwell Science Publications, Oxford, pp. 101-136.

Dasgupta M (1997). Biometry and length-weight relationship of the catfish Mystus gulio from West Bengal. Uttar Pradesh Journal of Zoology, 17: 241-244.

Davis MW (2000). Key principles for understanding fish by catch and discard mortality. Canadian Journal of Fisheries and Aquatic Sciences, 59: 1834-1843.

Froese $\mathrm{R}$ (2006). Cube law, condition factor and weight length relationship: History meta-analysis and recommendations. Journal of Applied Ichthyology, 22: 241-253.

Froese R and Pauly D (2018). Fish base, World Wide Web electronic publication. Available at: http://uww.fishbase.org.

Fulton TW (1904). The rate of growth of fishes, Twenty-second Annual Report, Part III. Fisheries Board of Scotland, Edinburgh, pp. 141-241.

Gupta S (2014). Morphology, growth pattern, feeding and reproductive biology of Mystus gulio (Hamilton-Buchanan 1822) (Siluriformes: Bagridae). International Journal of Aquatic Biology, 2(4): 201-205.

Haroun ES, Akel KH and Karachle PKN (2017). The marine ichthyofauna of Egypt. Egyptian Journal of Aquatic Biology and Fisheries, 21(3): 81-116.

Hossain MY, Ahmed ZF, Leunda PM, Jasmine S, Oscoz J, Miranda R and Ohtomi J (2006). Condition, length-weight and length-length relationships of the Asian striped catfsh Mystus vittatus (Bloch 1794) (Siluriformes: Bagridae) in the Mathabhanga River, southwestern Bangladesh. Journal of Applied Ichthyology, 22: 304-307.

Hossain MY, Jewel MAS, Nahar L, Rahman MM, Naif A and Ohtomi J (2012). Gonadosomatic index-based size at first sexual maturity of the catfish Eutropiichthys vacha (Hamilton, 1822) in the Ganges River (NW Bangladesh). Journal of Applied Ichthyology, 28: 601-605.

Hossain MY, Hossen MA., Pramanik MNU, Sharmin S, Nawer F, Naser SMA, Bahkali AH and Elgorban AM (2016a). Length-weight and length- length relationships of five Mystus species from the Ganges and Rupsha Rivers, Bangladesh. Journal of Applied Ichthyology, 32: 994-997. 
Hossain MY, Hossen MA, Pramanik MNU, Ahmed ZF, Hossain MA and Islam MM (2016b). Length-weight and lengthlength relationships of three Ambassid fishes from the Ganges River (NW Bangladesh). Journal of Applied Ichthyology, 32: 1279-1281.

Islam MA, Begum M, Alam MJ, Pal HK and Shah MMR (2007). Growth and survival of estuarine catfish, Mystus gulio (Ham.) larvae fed on live and prepared feeds. Bangladesh Journal of Zoology, 35: 325-330.

Khallaf E, Galal M and Athuman M (2003). The biology of Oreochromis niloticus in a polluted canal. Ecotoxicology, 12: 405-416.

Kohler CC and Kelly AM (1991). Assessing predator-prey balance in impoundments. In: Proceedings of the Warm water Fisheries Symposium, pp. 257-260.

Le Cren ED (1951). The length-weight relationship and seasonal cycle in gonad weight and condition in the perch (Perca fluviatilis). Journal of Animal Ecology, 20: 201-219.

Menon AGK (1999). Check list fresh water fishes of India. Record of the Zoological Survey of India, Occ. Paper. No., 175: $1-366$

$\mathrm{Ng} \mathrm{HH} \mathrm{(2010).} \mathrm{Mystus} \mathrm{gulio.} \mathrm{The} \mathrm{IUCN} \mathrm{Red} \mathrm{List} \mathrm{of} \mathrm{Threatened} \mathrm{Species} 2010$. doi:10.2305/IUCN.UK.2010,4.RLTS.T166491A6220391.en.

Panda D, Karna SK, Mukherjee M, Manna RK, Suresh VR and Sharma AP (2016). Length-weight relationships of six tropical fish species from Chilika Lagoon, India. Journal of Applied Ichthyology, 32: 1286-1289.

Pantulu VR (1961). Determination of age and growth of Mystus gulio (Ham.) by the use of pectoral spines, with observations on its biology and fishery in the Hooghly estuary. Proceedings of the National Institute of Science, India, 27: 198-225.

Porath MT and Peters EJ (1997). Use of walleye relative weights (WR) to assess prey availability. North American Journal of Fisheries Management, 17: 628-637.

Riede K (2004). Global register of migratory species- from global to regional scales. Final Report of the R\&D-Projekt 80805081. Federal Agency for Nature Conservation, Bonn, Germany, pp. 329.

Rypel AL and Richter TJ (2008). Empirical percentile standard weight equation for the blacktail redhorse. North American Journal of Fisheries Management, 28: 1843-1846.

Shulman MJ and Ogden JC (1987). Hot controls tropical reef-fish population recruitment or benthic mortality? An example in the Caribbean reef fish Haemulon flabolineatum. Marine Ecology Progress Series, 39: 233-242.

Sokal RR and Rohlf FJ (1987). Introduction to Biostatistics. $2^{\text {nd }}$ Ed. New York, Freeman Publication.

Talwar PK and Jhingran AG (1991). Inland Fishes of India and Adjacent Countries. Balkema AA (Ed.), Rotterdam, The Netherlands.

Tesch FW (1971). Age and growth. In: Methods for assessment of fish production in fresh waters, Ricker WE (Ed.), Oxford Blackwell Scientific Publications.

Weatherley AH and Gill HS (1987). Growth increases produced by bovine growth hormone in grass pickerel, Esox americanus vermiculatus (Le Sueur), and the underlying dynamics of muscle fiber growth. Aquaculture, 65: 55-66. 